\title{
Soil fertility evaluation of rice soils of Lumbajong block of Karbi Anglong district under hill zone of Assam through nutrient indexing
}

Nilim Kalita and Subal Maibangsa

Received : 18.07.2020; Revised : 05.11.2020; Accepted : 17.11 .2020

MEMBERS OF RESEARCH FORUM:

Corresponding author :

Nilim Kalita, Krishi Vigyan Kendra (AAU), Karbi Anglong, Diphu (Assam) India

Email: nilimkalitakvk@gmail.com
Co-authors :

Subal Maibangsa, Krishi Vigyan Kendra (AAU), Karbi Anglong, Diphu (Assam) India

\section{Summary}

The Lumbajong block of Karbi Anglong district of Assam is characterized by undulating topography comprising of hillocks and lowland paddy fields. Cultivation of rice in traditional ways for years without adequate and balanced use of chemical fertilizers and with little or no use of organic manure have caused severe fertility deterioration resulting in stagnating or even declining productivity of the paddy field soils. Spatial distributions for organic carbon, available $\mathrm{N}$, available $\mathrm{P}$ and available $\mathrm{K}$ were examined in the soil samples of selected rice fields in 102 different locations covering six villages in the block to evaluate the fertility status of the block. The study revealed that there is much variation in soil fertility status of soils developed on various land forms in the area as the soils were having low to high in organic carbon ( 0.42 to $1.12 \%)$, low to medium in available nitrogen $(175.62$ to $376 \mathrm{~kg} / \mathrm{ha})$ content; low in available P (3.86 to $28.29 \mathrm{~kg} / \mathrm{ha}$ ) and low to high in available $\mathrm{K}(71.68-439.04 \mathrm{~kg} / \mathrm{ha})$ contents. The soils of Lumbajong block were characterized as medium-medium-low-medium (MMLM) category based on the nutrient index calculated with respect to organic carbon, available $\mathrm{N}$, available $\mathrm{P}$ and available $\mathrm{K}$.

Key words : Hillocks, Nutrient index, Soil fertility, Karbi Anglong

How to cite this article : Kalita, Nilim and Maibangsa, Subal (2020). Soil fertility evaluation of rice soils of Lumbajong block of Karbi Anglong district under hill zone of Assam through nutrient indexing. Asian J. Soil Sci., 15(2): 81-85 : DOI : 10.15740/HAS/AJSS/15.2/81-85. Copyright@2020: Hind AgriHorticultural Society. 
higher crop production in Assam. Intensive agriculture without adequate and balanced use of chemical fertilizers, non-ecofriendly tillage practices and with little or no use of organic manure caused severe fertility deterioration of agricultural soils resulting in stagnating or even declining of crop productivity (Barua and Bora, 1975).

The term 'paddy soil' does not describe a specific soil type but rather denotes soils in lowland rice production systems with a prolonged period under submergence. Wetland rice or paddy soils provide the staple diet for nearly half the world's population (Witt and Haefele, 2005). Therefore, monitoring of the fertility of the paddy soils is of vital importance to sustain their productivity.

Sound knowledge about soil fertility status is very much relevant for identifying constraint in crop husbandry for attaining sustained productivity (Kumar et al., 2009). Frequently, loss of productivity has been related to the loss of soil organic matter (SOM) and stored nutrients that result from cultivation (Juo and Manu, 1996). Therefore, information for major nutrients including micronutrients is essential to achieve balance nutrition to overcome soil fertility problem and improve soil fertility on a sustainable basis.

In order to compare the level of soil fertility of an area with that of another it is necessary to obtain a single value for each nutrient. Nutrient index (N.I) value is a measure of nutrient supplying capacity of soil to plants (Singh et al., 2016). The nutrient index approach introduced by Parker et al. (1951) has been adopted and modified by several researchers such as Vishwanath Shetty et al. (2008); Pathak (2010); Sidharam et al. (2017); Chase and Singh (2014) and Amara et al. (2017). This index is used to evaluate the fertility status of soils based on the samples in each of the three classes, i.e., low, medium and high.

The Lumbajong block of Karbi Anglong district of Assam is characterized by undulating topography comprising of hillocks and lowland paddy fields. Stagnating or even declining productivity of the paddy field soils of the block may be ascribed to cultivation of rice in traditional ways for years without adequate and balanced use of chemical fertilizers and with little or no use of organic manure which have caused severe fertility deterioration (Baruah et al., 2013). Therefore, an attempt was made to evaluate the fertility of the rice soils through nutrient indexing for organic carbon, available N, available $P$ and available $K$.

\section{Resource and Research Methods}

\section{Study area:}

Karbi Anglong district is situated in the central part of Assam between $25^{\circ} 32^{\prime} \mathrm{N}$ to $26^{0} 36^{\prime} \mathrm{N}$ latitudes and $92^{\circ} 10^{\prime} \mathrm{E}$ to $93^{\circ} 50^{\prime} \mathrm{E}$ longitude. The Lumbajong block of Karbi Anglong district of Assam is under hill zone of Assam and around forty per cent area of the block is plain where winter paddy is the dominant crop. The region witnesses typical sub-tropical monsoon climate characterized by high relative humidity ( 73 to $84 \%$ ) throughout the year. The climate is mainly influenced by south-west monsoon from Bay of Bengal. The overall climate is characterized by hot and moist summer and cool winter.

\section{Soil sampling :}

One hundred two representative sites from the paddy fields in Lumbajong blocks of Karbi Anglong district of Assam were selected for the characterization of the soil. The paddy fields were characterized by

\begin{tabular}{|c|c|c|c|}
\hline Parameters & Low & Medium & High \\
\hline Organic carbon $(\%)$ & Below 0.5 & $0.5-0.75$ & Above 0.75 \\
\hline Available $\mathrm{N}(\mathrm{kg} / \mathrm{ha}$ & Below 272.0 & $272.0-544.0$ & Above 544.0 \\
\hline Available P (kgha) & Below 22.5 & $22.5-56.0$ & Above 56.0 \\
\hline Available $\mathrm{K}$ (kg/ha) & Below 136.0 & $136.0-336.0$ & Above 336.0 \\
\hline
\end{tabular}

\begin{tabular}{|lcl|}
\hline Table B : Nutrient index with range and remarks & Range & Remarks \\
\hline Nutrient index & Below 1.67 & Low fertility status of the area \\
I & $1.67-2.33$ & Medium fertility status of the area \\
II & Above 2.33 & High fertility status of the area \\
III &
\end{tabular}


traditional rice cropping system with low-medium productivity and unbalanced fertilizers use. Soil samples from the surface soil to a depth of $0-15 \mathrm{~cm}$ were collected from the paddy fields of six nos. of villages during November 2016-17 (post-monsoon).

\section{Soil analysis :}

The soil samples were air dried ground and sieved through $2 \mathrm{~mm}$ sieve. The processed soil samples were analyzed for basic soil parameters ( $\mathrm{pH}, \mathrm{EC}$ and OC) and for macronutrients $(\mathrm{N}, \mathrm{P}, \mathrm{K})$ by using standard procedures (Jackson, 1973); Bray's method (Bray and Kurtz, 1945) and neutral normal ammonium acetate, respectively.

\section{Nutrient index}

To evaluate the soil fertility status in Lumbajong Block, nutrient index with respect to organic carbon, available nitrogen, available phosphorus and available $\mathrm{K}$ were calculated based on the specific rating chart (Table A). Interpretations of the different values of soil nutrient index are given in Table B. The nutrient index in soil was evaluated for the soil samples analyzed using the following formula:

Nutrient index $($ N.I. $)=(\mathrm{NL} \times 1+\mathrm{NM} \times \mathbf{2}+\mathrm{NH} \times 3) / \mathrm{NT}$

where, NL: Indicates number of samples falling in low class of nutrient status NM : Indicates number of samples falling in medium class of nutrient status $\mathrm{NH}$ : Indicates number of samples falling in high class of nutrient status NT : Indicates total number of samples analysed for a given area.

\section{Research Findings and Discussion}

The results obtained from the present investigation as well as relevant discussion have been summarized under following heads :

\section{Organic carbon:}

Soil organic carbon is widely regarded as the single most important indicator of soil fertility and controls erosion and runoff of the soil and water, besides it is a major determinant of improved soil structure, moisture content and general nutrient status of the soil. Organic carbon content of the rice field soils of the study area ranged from 0.42 to 1.12 per cent with an average value of 0.58 (Table 1) and had maximum samples $(82.35 \%)$ under medium category followed by high category $(14.7 \%)$ (Table 2). The medium to high status of organic carbon in rice field soils may be attributed to single cropping of rice with maximum period of fallow, incorporation of left over stubbles and weed biomass, which leads to maintenance of organic matter content.

\section{Nutrient status :}

Available nitrogen :

Nitrogen is commonly limiting nutrient for plant growth in tropical soils and its availability is important to soil fertility (Maithani et al., 1998). Available nitrogen content of the soils of the study area varied from 175.62 $-376.00 \mathrm{~kg} \mathrm{ha}^{-1}$ (Table 1) with an average value of 247.9

\begin{tabular}{|c|c|c|}
\hline Parameters & Range & Mean+SD \\
\hline $\mathrm{pH}$ & $4.7-6.9$ & $5.33+0.360$ \\
\hline $\mathrm{EC}\left(\mathrm{dS} \mathrm{m} \mathrm{m}^{-1}\right)$ & $0.030-0.894$ & $0.118+0.096$ \\
\hline $\mathrm{OC}(\%)$ & $0.42-1.12$ & $0.58+0.113$ \\
\hline Available $\mathrm{N}\left(\mathrm{kg} \mathrm{ha}^{-1}\right)$ & $175.62-376$ & $247.19+32.130$ \\
\hline Available $\mathrm{P}_{2} \mathrm{O}_{5}\left(\mathrm{~kg} \mathrm{ha}^{-1}\right)$ & $3.86-28.29$ & $14.108+5.774$ \\
\hline Available $\mathrm{K}_{2} \mathrm{O}\left(\mathrm{kg} \mathrm{ha}^{-1}\right)$ & $71.68-439.04$ & $173.58+71.91$ \\
\hline
\end{tabular}

\begin{tabular}{|c|c|c|c|c|c|}
\hline \multirow{2}{*}{ Fertility parameters } & \multicolumn{3}{|c|}{$\%$ of samples } & \multirow{2}{*}{ Nutrient index } & \multirow{2}{*}{ Fertility rating } \\
\hline & Low & Medium & High & & \\
\hline $\mathrm{OC}$ & 2.9 & 82.35 & 14.7 & 2.11 & Medium fertility stat us of the area \\
\hline $\mathrm{N}$ & 24 & 76 & - & 1.76 & Medium fertility stat us of the area \\
\hline $\mathrm{P}$ & 98 & 2 & - & 1.02 & Low fertility stat us of the area \\
\hline $\mathrm{K}$ & 17 & 73 & 10 & 1.62 & Medium fertility stat us of the area \\
\hline
\end{tabular}


$\mathrm{kg} \mathrm{ha}^{-1}$. The available nitrogen content in the rice soils was low to medium range where 76 per cent soil samples were found in medium content of available nitrogen. As the organic matter content in the study area was found in medium range, the plant available nitrogen content in soils was observed consequently low to medium (Singh et al., 2018) The medium available nitrogen may be attributed to the higher biological activity as rice is cultivated as organic by default. Besides, low surface run off was observed in these fields which restrict the loss of mobile nitrogen.

\section{Available phosphorus :}

Available phosphorus $\left(\mathrm{P}_{2} \mathrm{O}_{5}\right)$ content of soils varied from 3.86-28.29 $\mathrm{kg} \mathrm{ha}^{-1}$ (Table 1) which can be rated as low. Considering $22.5 \mathrm{~kg} \mathrm{ha}^{-1}$ as the critical limit for $\mathrm{P}_{2} \mathrm{O}_{5}$, 98 per cent samples were found deficient in phosphorus (Table 2). Acidic soils fix P resulting in low available $P$. Plant uptake, erosion, leaching and fixation can be accounted for lower amount of P (Chase and Singh, 2014). The low content of available $P$ in these soils might be due to higher fixation of phosphorus by $\mathrm{Fe}^{2}, \mathrm{Mn}^{2+}$ and $\mathrm{Al}^{3+}$ (Laskar et al., 1983).

\section{Available potassium:}

The status of $\mathrm{K}_{2} \mathrm{O}$ in soils was found to be medium in range as it varied from $71.68-439.04 \mathrm{~kg} \mathrm{ha}^{-1}$ (Table 1). Taking $136.0 \mathrm{~kg} \mathrm{ha}^{-1}$ as the critical limit, only 17 per cent samples were found deficient in available potassium (Table 2). Adequate availability of $\mathrm{K}_{2} \mathrm{O}$ in these soils may be attributed to presence of K-rich minerals like mica, illite etc (Basumatary et al., 2014). But due to high rain fall and growing of rice for years together without addition of potassic fertilizers has lead to draining of $\mathrm{K}$ in certain areas of the block.

\section{Nutrient index:}

The nutrient index values in respect to organic carbon, available $\mathrm{N}$, available $\mathrm{P}$ and available $\mathrm{K}$ are 2.11, 1.76, 1.02 and 1.62, respectively (Table 2). Based on the criteria given in Table B (Rammoorthy and Bajaj, 1969), the rice field soils of Lumbajong block were categorized into medium-medium-low-medium (MMLM) category based on $\mathrm{OC}$, available $\mathrm{N}$, available $\mathrm{P}$ and available $\mathrm{K}$ concentrations, respectively.

\section{Conclusion:}

Majority of the soil samples appear to possess low to medium available $\mathrm{N}$, available $\mathrm{P}$ and available $\mathrm{K}$ except organic carbon content where majority of samples fall under medium to high. Considering the concept of nutrient index value, the soil of investigated area were found 'medium fertility status' for organic carbon, available nitrogen, available potassium and low with respect of available phosphorus.

Soils with low to medium phosphorus content in the study area can be supplemented by applying phosphorous rich fertilizers as required by the crop. Long-term continuous cultivation of paddy without application of any external inputs may further degrade the fertility of these agricultural fields. Therefore, judicious application of organics and soil test based application of inorganic fertilizers is of paramount importance to sustain the productivity of these rice fields.

\section{Acknowledgement:}

The authors are thankful to Dr. P.K. Pathak, Director of Extension Education, Assam Agricultural University, Jorhat, Assam for support to carry out this study.

\section{Literature Cited}

Amara, D. M. K., Patil, P. L., Kamara, A. M. and Saidu, D. H. (2017). Assessment of soil fertility status using nutrient index approach. Academia J. Agric. Res., 5(2) : 28-38.

Barua, P.K and Bora, P.K. (1975). Fertility status of the soils of North Eastern region. J. North Eastern Council, 1(2): 2126.

Baruah, B.K., Das, B. Medhi, C. and Misra, A.K. (2013). Fertility Status of Soil in the Tea Garden Belts of Golaghat District, Assam, India J.Chemistry, http://dx.doi.org/10.1155/ 2013/983297.

Basumatary, A. Baruah, R. and Medhi, B.K. (2014). Spatial variability of fertility status of soils of upper Brahmaputra valley zone of Assam. Asian J. Soil Sci., 9(1):142-148.

Bray, R.H. and Kurtz, L.T. (1945). Determination of total, organic and available forms of phosphorus. Soil Sci., 59 (1): $39-45$.

Chase, P. and Singh, O.P. (2014). Soil nutrients and fertility in three traditional land use systems of Khonoma, Nagaland, India. Resources \& Environment, 4(4): 181-189.

Jackson, M.L. (1973). Soil chemical analysis. Prentice Hall of Indian Pvt. Limited. New Delhi (India).

Juo, A.S.R. and Manu, A. (1996). Chemical dynamics in slashand-burn agriculture.Agriculture, Ecosystems \& Environment, 
58: 49-60.

Kumar, R., Sankar, A.K., Singh, K.P., Agarwal, B.K. and Karmakar, S. (2009). Appraisal of available nutrients status in santhal paraganas region of Jharkhand. J. Indian Soc. Soil Sci., 57 (3) : 366-369.

Laskar, S., Dahwal, K.S. and Prasad, R.N. (1983). Soils of Tripura and their fertility management. Research Bulleting of ICAR Research Complex for NEH Region, Shillong, (Tripura Centre). 23:31-36.

Maithani, K., Arunachalam, A., Tripathi, R.S. and Pandey, H.N. (1998). Nitrogen mineralization as influenced by climate, soil and vegetation in a subtropical humid forest in North East India. Forest Ecology \& Management, 109:91-101.

Nambiar, K.K.M. and Abrol, I.P. (1989). Long term fertilizer experiments in India: An overview. Fertilizer News, 34 (4): 1120.

Parker, F. W., Nelson, W. L., Winters, E. and Miles, I. E. (1951). The broad interpretation and application of soil test information. Agron. J., 43 (3) : 105-112.

Pathak, H. (2010). Trend of fertility status of Indian soils. Current Adv. Agric. Sci., 2(1): 10-12.
Ramamurthy, B. and Bajaj, J.C. (1969). Soil fertility map of India, Indian Agricultural Research Institute, New Delhi, India.

Sidharam, P., Kumar, K. S. A. and Srinivasamurthy, C. A. (2017). Soil fertility status and nutrient index for primary nutrients in Western Ghats and Coastal Karnataka under different agro-ecological systems. Asian J. Soil Sci., 12(2):314319.

Singh, G., Sharma, M., Manan, J. and Singh, G. (2016). Assessment of soil fertility status under different cropping sequences in district Kapurthala. J. Krishi Vigyan, 5 (1) : 1-9.

Singh, S.P., Singh, S., Kumar, A. and Kumar, R. (2018). Soil fertility evaluation for macronutrients using parkers nutrient index approach in some soils of Varanasi district of Eastern Utter Pradesh, India. Int. J. Pure App. Biosci., 6(5): 542-548.

Vishwanath Shetty, Y., Nagamma, M. S., Dinesh Kumar, M., and Jayaprakash, S.M. (2008). Fertility status in arecanut garden soils of Karnataka. Karnataka J. Agric. Sci., 21(4):503506.

Witt, C. and Haefele, S.M. (2005). Paddy soils In: Encyclopedia of soils in the environment (Hillel D., Ed.) 3:141150. https://doi.org/10.1016/B0-12-348530-4/00286-1. 